\title{
Interactions between invasive crayfish and native river shrimp
}

\author{
F. Banha ${ }^{(1)}$, P.M. Anastácio(1)
}

Received December 24, 2010

Revised March 17, 2011

Accepted April 19, 2011 Key-words:
interaction,
Athyaephyra
desmarestii,
Procambarus
clarkii,
predation,
habitat use

\section{ABSTRACT}

In the south of Portugal there are only two species of strictly freshwater decapods: the native freshwater shrimp Atyaephyra desmarestii and the exotic crayfish Procambarus clarkii. The aim of this study is to understand if the exotic crayfish acts as river shrimp predator and if both species share the same type of microhabitat. We performed laboratory experiments to study predation and conducted field work in the river Sorraia to verify the microhabitat distribution of both species. Laboratory experiments demonstrated significant predation on river shrimp for crayfish with a cephalothorax length $(C T)$ over $24 \mathrm{~mm}$. The average daily consumption increases with crayfish $C T$ to a maximum of 0.8 shrimps at $44 \mathrm{~mm}$. Field work confirmed that both species share the same microhabitats although with small differences e.g. on the water quality variables such as conductivity and the percentage of oxygen saturation. These microhabitats are shallow pools with abundant aquatic vegetation with no preference for the type of substrate. In the field, both crayfish density and its cephalothorax length are negatively correlated with shrimp densities. In conclusion, $P$. clarkii can predate $A$. desmarestii and the major impacts are expected at high densities of large sized crayfish.

\section{RÉSUMÉ}

\section{Interactions entre écrevisse invasive et crevette native en rivière}

\author{
Mots-clés : \\ interaction, \\ Athyaephyra \\ desmarestii, \\ Procambarus \\ clarkii, \\ prédation, \\ habitat
}

Dans le sud du Portugal, il n'y a que deux espèces de décapodes strictement d'eau douce : la crevette indigène d'eau douce Atyaephyra desmarestii et l'écrevisse exogène Procambarus clarkii. Le but de cette étude est de comprendre si l'écrevisse exogène agit comme prédateur de la crevette et si les deux espèces partagent le même type de microhabitat. Des expériences de laboratoire ont été réalisées pour étudier la prédation et des travaux sur le terrain dans la rivière Sorraia pour vérifier la distribution des microhabitats des deux espèces. Les expériences de laboratoire montrent une prédation significative sur la crevette palomète par l'écrevisse dont la longueur du céphalothorax $(C T)$ est supérieure à $24 \mathrm{~mm}$. La consommation moyenne journalière augmente avec la taille CT de l'écrevisse jusqu'à un maximum de 0,8 crevette à $44 \mathrm{~mm}$. Le travail de terrain confirme que les deux espèces partagent les mêmes microhabitats bien qu'avec de petites différences concernant des variables de qualité des eaux comme la conductivité et le pourcentage de saturation en oxygène. Ces microhabitats sont des calmes peu profonds avec une abondante végétation aquatique sans préférence pour le type

(1) IMAR-Instituto do Mar and Departamento de Paisagem, Ambiente e Ordenamento, Universidade de Évora, Rua Romão Ramalho, $n^{\circ}$ 59, 7000-671 Évora, Portugal, fibanha@yahoo.com.br 
de substrat. Dans le milieu naturel, densité d'écrevisse et longueur du céphalothorax sont toutes deux corrélées négativement avec la densité de crevettes. En conclusion, $P$. clarkii est prédatrice d'A. desmarestii et l'impact majeur est estimé aux hautes densités de grandes écrevisses.

\section{INTRODUCTION}

Biological invasions are one the major causes of biodiversity loss and Man is directly or indirectly responsible for the introduction of numerous exotic species. Freshwater ecosystems are the second largest reservoir of biodiversity, after the rainforests, and are especially vulnerable to biological invasions (Costanza et al., 1997). Invaders can threaten native species through competition, predation and introduction of new diseases, causing negative impacts on the structure and functioning of ecosystems (Hobbs et al., 1989; Holdich, 1999). Freshwater crustaceans are one of the most documented groups of freshwater invaders and are responsible for declines and extinctions of native species throughout the world (Guan and Wiles, 1997; Lodge et al., 1998, 2000; Nyström et al., 2001, Westman et al., 2002). The red swamp crayfish, Procambarus clarkii (Girard, 1852) is endemic to southeastern North America and, with the exception of Australia and Antarctica, it was successfully introduced on every continent due to its food value and economic importance (Hobbs et al., 1989). In several invaded water bodies, $P$. clarkii became the dominant organisms in terms of biomass, and are major consumers in their ecosystem (Flint and Goldman, 1975; Momot et al., 1978). Despite being opportunistic omnivores, they may often feed selectively on macrophytes, macroinvertebrates and amphibians, strongly affecting their populations and causing direct impacts (Correia, 2003). In Portugal, the first record of $P$. clarkii dated from 1979 in the Caia river, (Ramos and Pereira, 1981), but currently it has spread throughout the whole country due to rapid population growth and abundance of favorable habitats (Correia, 1995). Although numerous studies focus on the consequences of the introduction of this species, there are still unknown impacts caused by $P$. clarkii on the native river shrimp Athyaephyra desmarestii (Millet, 1831). A. desmarestii is a phytophilous, eurythermal and euryhaline crustacean, who prefers slow flowing waters, rich in macrophytes and dissolved oxygen (Fidalgo and Gerhardt, 2002). The original distribution of the river shrimp was restricted to North Africa and southern Europe (Tittizer, 1996). In recent years it expanded its distribution, colonizing rivers of central Europe, reaching the Baltic, and the Northern and Black seas (Fidalgo and Gerhardt, 2002). A. desmarestii has been found in many Portuguese freshwaters, including reservoirs, rice fields, coastal lagoons and temporary streams (Fidalgo and Gerhardt, 2002). This species is omnivorous, eating a wide variety of food items such as algae, mud and even fecal matter. It has an important role in freshwater ecosystems due to the recycling of organic matter (Fidalgo, 1990) and also because it constitutes an important food item for many fish species (García-Berthou and Moreno-Amich, 2000a, 2000b; García-Berthou, 2001, 2002). Based on the previously described distribution of $A$. desmarestii and $P$. clarkii in Portugal, and because both tend to occur in areas with abundant macrophyte cover (Fidalgo and Gehardt, 2002; Aquiloni et al., 2005), we believe that these species coexist in many areas. In this sense, given the lack of studies on this issue, we sought to understand the interactions between these two species. The present work aims to investigate whether or not $A$. desmarestii is preyed upon by $P$. clarkii, to evaluate the effect of $P$. clarkii's size on this prey and to assess in the field, if the presence of $P$. clarkii has an impact on the density of $A$. desmarestii.

\section{MATERIALS AND METHODS}

\section{> STUDY SITE}

The field work was carried out in an area of about $870 \mathrm{~km}^{2}$ in the Sorraia River basin. The Sorraia river is the major Portuguese tributary of the Tagus river basin and has a total 
drainage area of $7652 \mathrm{~km}^{2}$, occupying a large part of Central Portugal. Its basin has typical Mediterranean features: $80 \%$ of the rain falls during three winter months; it has a mean annual temperature of $16-18{ }^{\circ} \mathrm{C}$ and a natural absence of flow during an average of four months in many low order streams. Four large reservoirs distribute most of the outflow to the system of irrigation channels crossing the main river valley. A series of small reservoirs and weirs are used for local irrigation activities, affecting the river flow and increasing the period of summer drought (Ferreira and Moreira, 1999). The banks are covered with Salix spp. and the major macrophyte species are Myriophyllum aquaticum, Ceratophyllum demersum and Potamogeton fluitans (Geraldes and Collares-Pereira, 1995).

\section{> LABORATORY EXPERIMENTS}

To investigate whether $A$. desmarestii is preyed upon by $P$. clarkii and to evaluate the effect of $P$. clarkii's size on this prey, we used five blocks of 25 aerated containers with $58 \mathrm{~L}$ water. An artificial plant and five river shrimps were placed in each container and one crayfish was added 10 min later in 20 of the 25 containers. The remaining five containers acted as controls without crayfish. We used a total of 625 river shrimp with a mean total length $(T L)$ of $2.48 \mathrm{~cm} \pm 0.26$ S.D. and 100 crayfish of 4 size classes of cephalothorax length (CT): class $S$ $(<24 \mathrm{~mm})$, class $M(27-31 \mathrm{~mm})$, class $\mathrm{L}(36-44 \mathrm{~mm})$, class $X L(>44 \mathrm{~mm})$. We only used adult and sub-adult crayfish since preliminary experiments showed that small crayfish were unable to prey shrimp of similar or smaller size. In each experimental block we had an equal number of crayfish of each size class and size classes were randomly assigned to each tank. The experiment lasted $24 \mathrm{~h}$ and at the end we counted the number of river shrimp consumed in each container. On average, during the experiment, $\mathrm{pH}$ was $8.30 \pm 0.13$ S.D., temperature was $19.7^{\circ} \mathrm{C} \pm 0.6$ S.D. and oxygen saturation was $95.7 \% \pm 7.5$ S.D. The results were analyzed using the Kruskal-Wallis statistics followed by a post-hoc non-parametric multiple comparison test (Zar, 1996) with PASW Statistics v. 18.

\section{$>$ FIELD WORK}

The occurrence of $P$. clarkii and of $A$. desmarestii was checked from June 16 to July 4, 2007 in 20 spots with 10 sampling stations each, within the Sorraia river basin. At each $2 \mathrm{~m}^{2}$ area sampling station we dragged a quadrangular dip net $(1 \mathrm{~mm}$ mesh; $50 \mathrm{~cm} \times 30 \mathrm{~cm})$ five times and recorded water depth $(\mathrm{cm})$, percentage of vegetation cover (\%), most abundant macrophyte species, water current velocity $\left(\mathrm{m} \cdot \mathrm{s}^{-1}\right)$, bottom substrate particle dimensions, dissolved oxygen $\left(\mathrm{mg} \cdot \mathrm{L}^{-1}\right)$, oxygen saturation $(\%), \mathrm{pH}$, water temperature $\left({ }^{\circ} \mathrm{C}\right)$ and conductivity $\left(\mu \mathrm{s} \cdot \mathrm{cm}^{-1}\right)$ with a Multiline F-WTW probe. The number of river shrimp and crayfish captures was counted and crayfish cephalothorax length $(C T)$ was measured. To identify which environmental variables have a role in the distribution of the studied species, we conducted a binary logistic regression using the backward stepwise method with presence/absence of each of the species as the dependent variable and the environmental variables as independent variables. For each "species-environmental variable" pair we calculated niche amplitude (Levins, 1968) and we also calculated the niche overlap for each variable (Schoener, 1970). To obtain niche amplitude and niche overlap we calculated the mean densities of both species for each variable at each class interval. Class intervals were: water depth -8 classes of $15 \mathrm{~cm}(0-120 \mathrm{~cm}$ range); $\%$ vegetation cover -5 classes of $20 \%$ (0-100\% range); water current velocity -6 classes of $0.5 \mathrm{~m} \cdot \mathrm{s}^{-1}\left(0-3 \mathrm{~m} \cdot \mathrm{s}^{-1}\right.$ range); bottom substrate in Attenberg scale (llhéu, 2004), $1(<0.02 \mathrm{~mm})$; 2 (1-5 mm); $3(5-50 \mathrm{~mm}) ; 4$ (50-150 mm); 5 (150-500 mm); 6 (> $500 \mathrm{~mm})$; conductivity 6 classes of $100 \mu \mathrm{s} \cdot \mathrm{cm}^{-1}$ (200-800 $\mu \mathrm{s} \cdot \mathrm{cm}^{-1}$ range); water temperature, 6 classes of $2{ }^{\circ} \mathrm{C}$ $\left(15-27^{\circ} \mathrm{C}\right.$ range); dissolved oxygen -8 classes of $2 \mathrm{mg} \cdot \mathrm{L}^{-1}\left(4-20 \mathrm{mg} \cdot \mathrm{L}^{-1}\right.$ range); oxygen saturation -8 classes of $20 \%$ (40-200\% range); $\mathrm{pH}-4$ classes of 0.5 (7-9 range). A nonparametric Kruskal-Wallis test followed by a non-parametric post-hoc test (Zar, 1996) was used to compare the densities of both species at different substrate classes. For each sampling station the mean crayfish cephalothorax length $(C T)$ was calculated and placed within 


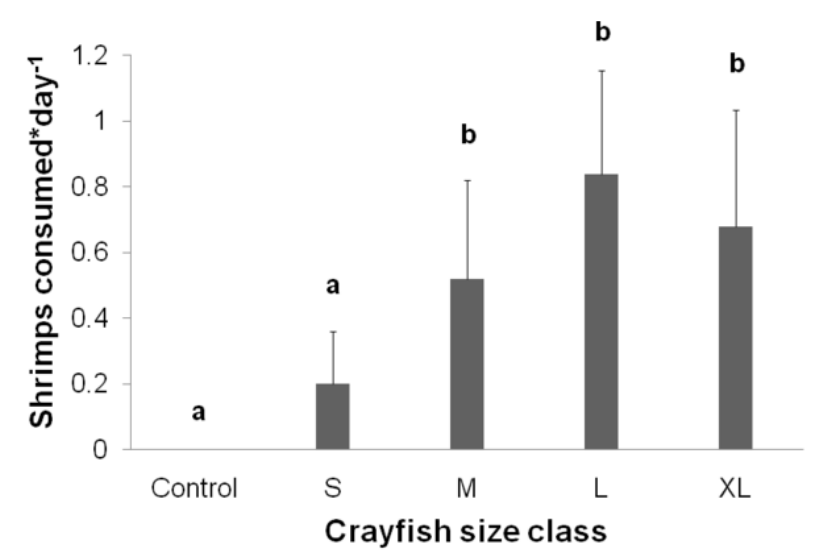

\section{Figure 1}

Results of the laboratory experiments testing the daily consumption of river shrimp by the red swamp crayfish. Mean values and 95\% confidence intervals are presented for each crayfish size class. Control tanks have no crayfish. Groups with the same letter $(a, b)$ are not statistically different (post-hoc test: $p>0.05)$.

\section{Figure 1}

Résultats des expériences de laboratoire testant la consommation journalière de crevettes palomète par l'écrevisse de Louisiane. Valeurs moyennes et intervalles de confiance à $95 \%$ sont présentés pour chaque classe de taille de l'écrevisse. Les aquariums témoins n'ont pas d'écrevisses. Les groupes avec la même lettre $(a, b)$ ne sont pas significativement différents (test post hoc : $p>0,05$ ).

each of six crayfish size classes $(0-10 \mathrm{~mm} ; 10-20 \mathrm{~mm} ; 20-30 \mathrm{~mm} ; 30-40 \mathrm{~mm} ; 40-50 \mathrm{~mm}$; $50-60 \mathrm{~mm}$ ). The availability of different crayfish sizes differed during laboratory and field work therefore affecting the choice of its size classes. The maximum shrimp density found for each crayfish size class was used in a linear regression relating average crayfish size and maximum shrimp density. Another linear regression was calculated for the highest densities of river shrimp as a function of crayfish density.

\section{RESULTS}

All river shrimp survived in the control containers and crayfish size had a significant effect on shrimp survival (Kruskal-Wallis: $X^{2}=26.638$; $\mathrm{df}=4 ; N=125 ; P<0.001$ ). The average number of shrimps consumed increased with crayfish length to a maximum of 0.82 shrimps consumed per day at class $L$ (Figure 1). The maximum consumption rate was of three river shrimps consumed per crayfish in one day and this was observed three times at three different classes (M, L, XL). The majority of size $S$ crayfish did not consume any shrimp and only 5 of 25 crayfish from this class consumed one shrimp per day. The post-hoc test for non-parametric multiple comparisons obtained significant differences between the controls and $M, L$ and $X L$ size classes (Table I). There were no significant differences between class $S$ and the control (Table I). The niche overlap (Figure 2), obtained from field data, shows that river shrimp and crayfish share the same microhabitats. The overlap was higher than $50 \%$ for all variables, except for the conductivity and dissolved oxygen. In fact, shallow pool areas with a water depth below $1 \mathrm{~m}$ and abundant vegetation cover, had the highest densities of both species. These densities reached 170 individuals $\cdot \mathrm{m}^{-2}$ and 8 individuals $\cdot \mathrm{m}^{-2}$, respectively for river shrimp and crayfish (Figure 3). In microhabitats with water depths above $95 \mathrm{~cm}$ or with a water current velocity over $1 \mathrm{~m} \cdot \mathrm{s}^{-1}$, no river shrimp or crayfish were found. We found no crayfish and very low densities of river shrimp in microhabitats without vegetation cover. In these microhabitats, river shrimp densities were mostly null or below 10 river shrimp. $\mathrm{m}^{-2}$. The highest densities of the two species did not match in respect to conductivity and oxygen saturation. The highest crayfish densities were found with high values of conductivity and high 


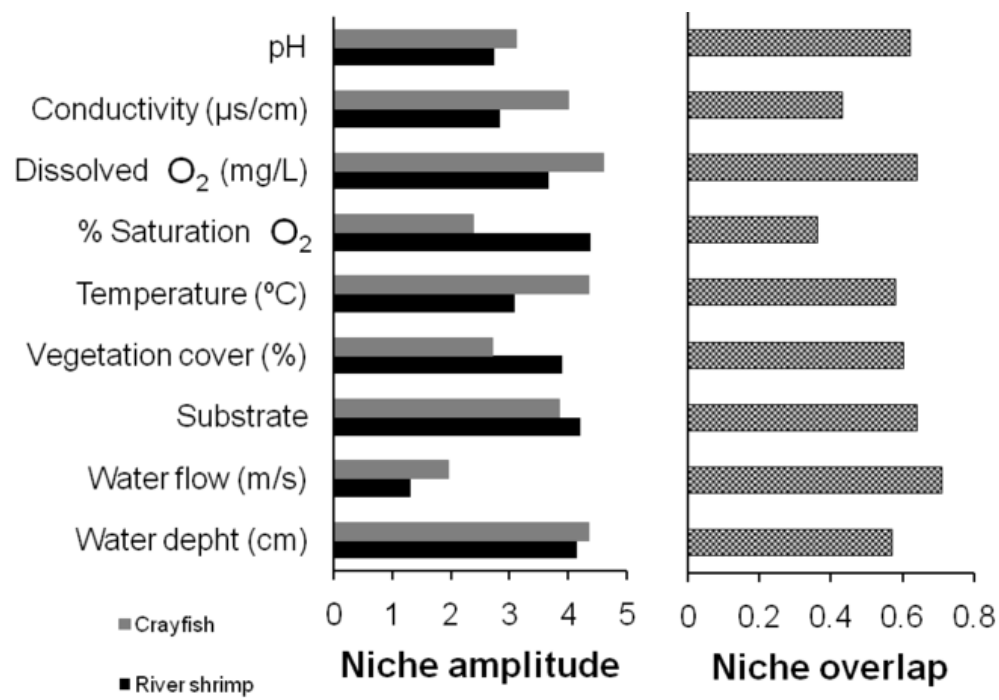

\section{Figure 2}

Niche amplitude (Levins, 1968) and niche overlap (Schoener, 1970) for river shrimp and red swamp crayfish.

\section{Figure 2 \\ Amplitude de niche (Levins, 1968) et recouvrement de niche (Schoener, 1970) pour la crevette palomète et l'écrevisse de Louisiane.}

\section{Table I}

Results for the post-hoc test for non-parametric multiple comparisons (Zar, 1996). Critical value of $Q_{(0.05 ; 4)}=2.807$.

\section{Tableau !}

Résultats du test post hoc de comparaisons multiples non-paramétriques (Zar, 1996). Valeur critique de $Q_{(0,05 ; 4)}=2,807$.

\begin{tabular}{|l|c|c|c|}
\cline { 2 - 4 } \multicolumn{1}{c|}{} & Standard error & $Q$ & $p$ values \\
\hline Control vs. S & 8.531 & 1.336 & $>0.05$ \\
Control vs. M & 8.531 & 2.881 & $<0.05$ \\
Control vs. L & 8.531 & 4.667 & $<0.05$ \\
Control vs. XL & 8.531 & 3.423 & $<0.05$ \\
\hline
\end{tabular}

values of oxygen saturation, and the opposite happened for river shrimp. There was no apparent tendency for river shrimp or crayfish densities regarding water temperature, dissolved oxygen and type of bottom substrate. River shrimp densities presented no clear tendency for $\mathrm{pH}$, although crayfish densities seemed to be lower at more alkaline conditions (Figure 3). There were no significant differences between river shrimp densities found in different substrate classes (Kruskal-Wallis: $X^{2}=2.994 ; \mathrm{df}=5 ; N=191 ; p=0.701$ ) nor at different crayfish densities (Kruskal-Wallis: $X^{2}=6.560$; df $=5 ; N=191 ; p=0.255$ ). The binary logistic regression to explain the presence/absence of river shrimp $\left(X^{2}=80.361 ; n=191 ; \mathrm{df}=3 ; p=0.000\right.$; -2 Log likelihood = 184.374; Cox and Snell $r^{2}=0.343$; Nagelkerke $r^{2}=0.458$ ) included the variables vegetation cover $(p=0.000)$; dissolved oxygen $(p=0.022)$ and water depth $(p=0.111)$ (Table II). This model successfully predicted presence or absence of river shrimps for $78.5 \%$ of the sites. The binary logistic regression model explaining the presence/absence of crayfish $\left(X^{2}=60.825 ; N=191 ; \mathrm{df}=5 ; p=0.000 ;-2\right.$ Log likelihood = 150.056; Cox and Snell $R^{2}=0.273$; Nagelkerke $\left.R^{2}=0.408\right)$ had five variables: vegetation cover $(p=0.000)$; $\mathrm{pH}(p=0.002)$; conductivity $(p=0.020)$; water depth $(p=0.023)$ and water flow $(p=0.028)$ (Table III). This model successfully predicted presence or absence of crayfish for $80.1 \%$ of the sites. Maximum river shrimp densities were negatively correlated with crayfish density 


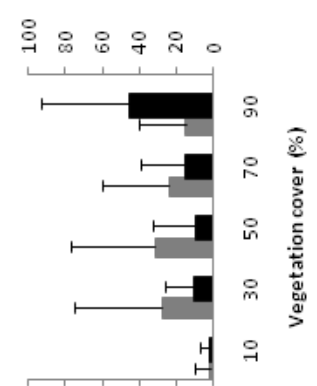

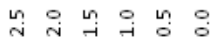
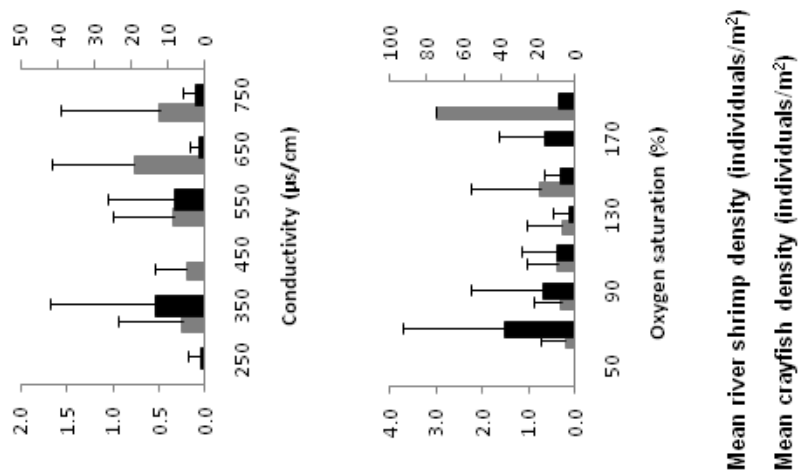

앙 웅 잉
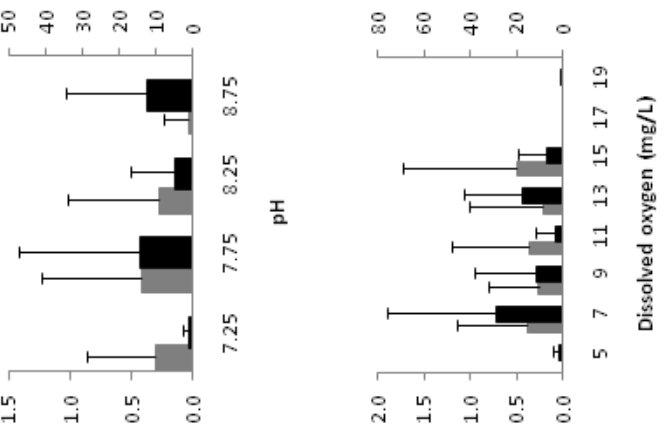

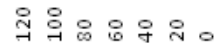
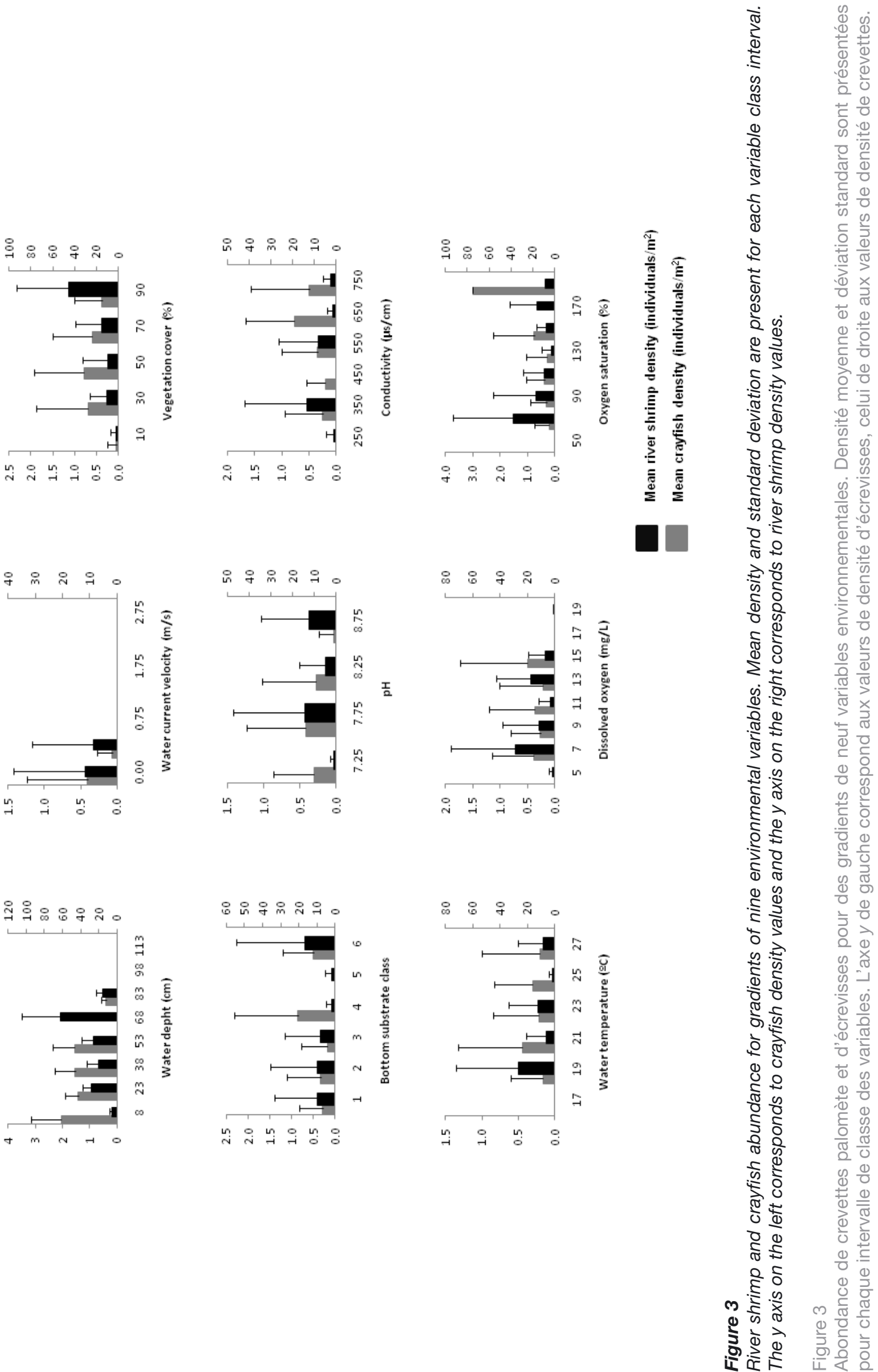


\section{Table II}

Parameter values obtained on a binary logistic regression predicting river shrimp density.

Tableau II

Valeurs des paramètres prédictifs de la densité de crevettes palomète par régression logistique.

\begin{tabular}{|l|c|c|c|c|c|c|}
\multicolumn{1}{c|}{} & $B$ & S.E. & Wald & df & $p$ values & Exp $(B)$ \\
\hline Water depth & -0.013 & 0.008 & 2.543 & 1 & 0.111 & 0.987 \\
Vegetation cover & 0.047 & 0.007 & 50.148 & 1 & 0.000 & 1.048 \\
Dissolved oxygen & 0.246 & 0.108 & 5.216 & 1 & 0.022 & 1.280 \\
Constant & -3.444 & 1.194 & 8.321 & 1 & 0.004 & 0.032 \\
\hline
\end{tabular}

\section{Table III}

Parameter values obtained by a binary logistic regression predicting crayfish density.

Tableau III

Valeurs des paramètres prédictifs de la densité d'écrevisses par régression logistique.

\begin{tabular}{|l|c|c|c|c|c|c|}
\cline { 2 - 6 } \multicolumn{1}{c|}{} & $B$ & S.E. & Wald & df & $p$ values & Exp $(B)$ \\
\hline Water depth & -0.024 & 0.011 & 5.179 & 1 & 0.023 & 0.976 \\
Water flow & -7.103 & 3.227 & 4.844 & 1 & 0.028 & 0.001 \\
Vegetation cover & 0.026 & 0.006 & 16.702 & 1 & 0.000 & 1.026 \\
Conductivity & 0.003 & 0.001 & 5.438 & 1 & 0.020 & 1.003 \\
pH & -1.709 & 0.562 & 9.258 & 1 & 0.002 & 0.181 \\
Constant & 11.333 & 4.647 & 5.948 & 1 & 0.015 & 83573.792 \\
\hline
\end{tabular}

(Figure 4) and with its cephalothorax length (Figure 5). The river shrimp densities attained the highest values in the absence of crayfish or in the presence of small crayfish. High densities of large crayfish were correlated with low river shrimp density.

\section{DISCUSSION}

Our experiments show that crayfish can predate river shrimps, despite their fast escape reactions that make them a difficult prey. In fact, according to Renai and Gherardi (2004), crayfish are able to prey species with fast escape reactions, such as amphibian larvae and trout fry. This ability is related to a "sit and wait" strategy in which the prey does not feel threatened and is eventually caught. We observed in the laboratory that both species seemed to spend most of their time in the artificial aquatic plant therefore sharing the same space. This fact, together with the crayfish capture strategy may explain the observed predation effect. $P$. clarkii has a significant predatory effect upon river shrimp for cephalothorax lengths over $24 \mathrm{~mm}$ (classes M, L, XL). In nature, the proportion of macroinvertebrates in the diet of crayfish decreases as their size increases, and the adults with a total length exceeding $11 \mathrm{~cm}$ are almost exclusively scavengers (Ilhéu and Bernardo, 1993). Moreover, crayfish effects on macroinvertebrate diversity decrease with crayfish size (Correia and Anastácio, 2008), reflecting a clear diet shift as crayfish growth. Despite a preference for detritus followed by fresh plant material, adult crayfish can feed mostly on animal material, according to the availability of macroinvertebrates (Ilhéu and Bernardo, 1993, 1995; Correia, 2002). In our opinion class S crayfish, did not cause significant predation effects because of similar prey and predator sizes. The maximum average consumption per individual, per day was found for the class $L$ ( 0.8 shrimps). This value is apparently low, but it is important to remember that crayfish have not gone through any period of fasting and were well fed before the experiment. It is also important to note that the density of prey, five per container, is a low density compared to the river shrimp density values found in nature which are up to 1811 animals per $\mathrm{m}^{2}$ (Meurisse-Génin et al., 1985; Fidalgo, 1990). Thus $P$. clarkii's predation may be stronger under natural conditions than under experimental conditions. 


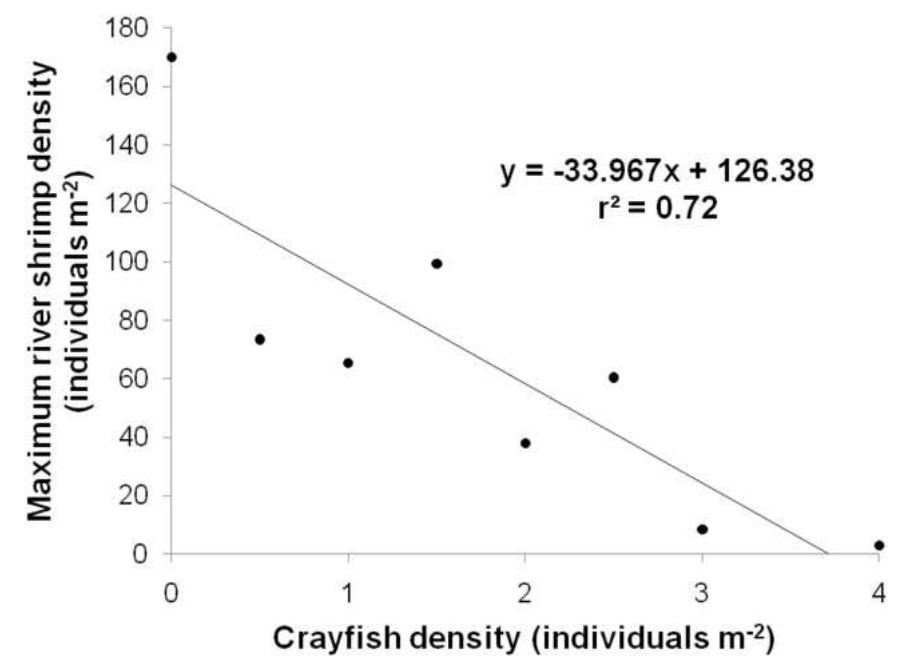

\section{Figure 4}

Maximum river shrimp density vs. crayfish density $(p=0.008)$.

Figure 4

Densité maximum de crevettes palomète $v s$. densité d'écrevisses $(p=0,008)$.

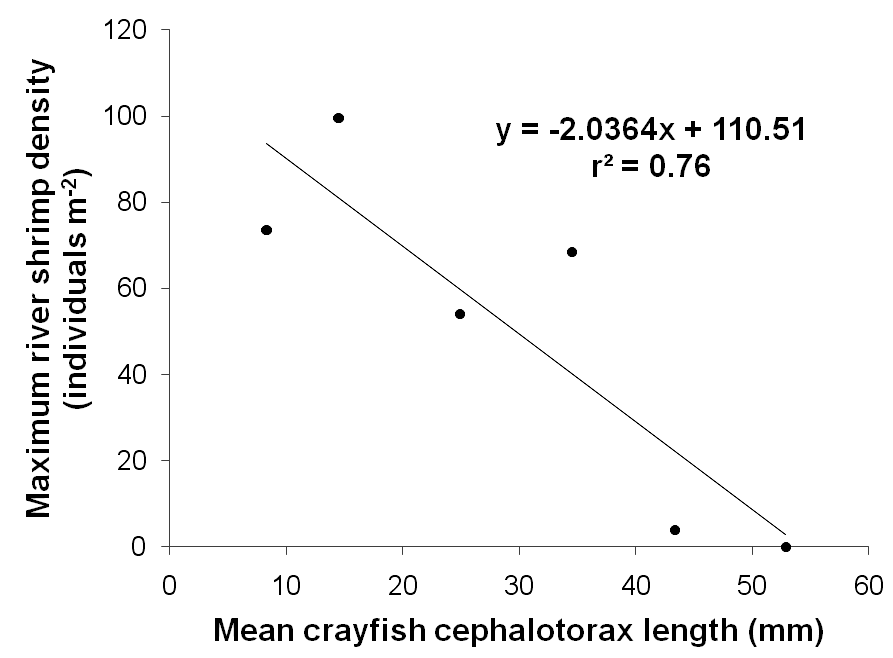

\section{Figure 5}

Maximum river shrimp density vs. crayfish cephalotorax length $(p=0.024)$.

\section{Figure 5}

Densité maximum de crevettes palomète vs. longueur du céphalothorax de l'écrevisse $(p=0,024)$.

Mediterranean freshwater systems are frequently confined to small areas due to drought during late summer and early autumn (Magalhães et al., 2002) and in those circumstances prey are heavily consumed by crayfish (Correia, 2003). Our field work was performed in early summer (late June to early July) when these confined conditions are beginning to emerge. We would expect that in species with completely different niches, the impact of invasive species on natives would be minimal or negligible. However, field results show that both species tend to share the same microhabitats and the highest densities of both species are found in shallow pools with macrophytes. In fact, the vegetation cover is important for $P$. clarkii as well as for other crayfish species, because high plant biomass microhabitats promote shelter (Garvey et al., 1994). Probably for the same reason the river shrimp occupies microhabitats with vegetation. For a related crayfish species, Procambarus alleni, population density also 
increases with plant biomass but decreases with water depth. Larger water depths are related with larger predatory fish (Heck and Crowder, 1991; Jordan et al., 1996), which may explain why both studied species prefer shallow waters. Further, Adão (1991) observed highest densities of $P$. clarkii at water depths below $40 \mathrm{~cm}$, therefore supporting this idea. According to this view it is not surprising that both species present the smallest niche amplitude for water depth.

There is a small niche overlap for conductivity and for the dissolved oxygen, two variables frequently associated to pollution and eutrophic waters. In spite of this, $P$. clarkii is extremely resistant to bad water quality (Arrignon et al., 1990), and high densities of this species can be found in places with a low value for the BMWP water quality index (Gil-Sánchez and Alba-Tercedor, 2002). The opposite happens for $A$. desmarestii, which is associated to good water quality in terms of the saprobic index, heavy metal contamination, acidification (Abdennour et al., 2000; Gerhardt et al., 2004) and IBMWP water quality index (Oscoz and Durán, 2005).

The binary logistic regressions performed for the presence/absence of both species reinforces the role of vegetation in the species distribution. This was the most important variable for both models. For the river shrimp, the variable "dissolved oxygen" comes second in order of importance. The probability of shrimp occurrence increases with higher oxygen saturation levels and actually Fidalgo and Gerhardt (2002) also referred that this species prefers waters rich in dissolved oxygen. The last variable integrated in this model was the water depth. The model predicts the decrease of the river shrimp's probability of presence with increasing water depth.

For the crayfish model, the most important variable to explain the presence of this species was the vegetation cover. The second variable was $\mathrm{pH}$ and the relation was negative. This agrees with Arrignon et al. (1990) who referred that ideally the $\mathrm{pH}$ range for crayfish is between 6.5 to 8.5. The range values found in this work were between 7.3 to 8.9, so the highest values we found, fall outside the ideal range. The third variable was conductivity which presented a negative slope, followed by water depth, also with a negative slope. The last variable that this model considers is water flow. According to Gil-Sánchez and Alba-Tercedor (2002), this variable was one the most important for $P$. clarkii distribution. In our model, the probability of crayfish presence is lower at high velocity water flow. Our results also suggest that in the study area none of the species had a substrate preference. In fact other authors (Gil-Sánchez and Alba-Tercedor, 2002; Cruz and Rebelo, 2007) also indicated an absence of association between crayfish distribution and substrate composition.

The fact that crayfish predate river shrimp and that these two species share the same microhabitats indicates a probable impact of crayfish on river shrimp populations. Procambarus clarkii has in fact been considered responsible for the disappearance of some macroinvertebrates in the aquatic ecosystems where it has been introduced (Geiger et al., 2005; Correia and Anastácio, 2008) and these results are in line with that perspective. Linear regressions, made for maximum river shrimp densities versus crayfish density, and mean crayfish cephalothorax length confirm that impacts are significant. We also verified that the highest crayfish and river shrimp densities occur in habitats with similar macrophytes species (Cynodon dactylon, Polygonum persica and Cyperus longus). According to Arrignon et al. (1990) in its home range the red swamp crayfish has a preference for Cyperus spp. macrophytes.

Another possible impact of crayfish on river shrimp populations is the loss of habitats, since we proved that river shrimp densities are directly correlated to vegetation cover and crayfish are often responsible for the disappearance of aquatic vegetation leading to habitat loss (Rodríguez et al., 2005). Several studies in the Iberian Peninsula (Anastácio and Marques, 1997; Vila-Escalé et al., 2002; Rodríguez et al., 2005) showed that, even at low densities (up to 1 individual $\cdot \mathrm{m}^{-2}$ ), crayfish can severely affect vegetation. Thus, river shrimp populations can be affected by the invasive red swamp crayfish through direct predation and by habitat loss. In conclusion, our work shows that the red swamp crayfish and river shrimp occupy the same type of microhabitats. Our field and laboratory data indicate that the crayfish have 
impacts on river shrimp populations, with the major effects being expected at high densities of large sized crayfish.

\section{ACKNOWLEDGEMENTS}

This work benefited from FEDER funds through the "Programa Operacional de Factores de Competitividade - COMPETE" and by national funds through "FCT - Fundação para a Ciênca e Tecnologia" on the scope of the project DID (Dispersal of Invasive Decapoda) (PTDC/BIA$\mathrm{BEC} / 105182 / 2008)$.

\section{REFERENCES}

Abdennour C., Smith B.D., Boulakoud M.S., Samraoui B. and Rainbow P.S., 2000. Trace metals in marine, brackish and freshwater prawns (Crustacea, Decapoda) from northeast Algeria. Hydrobiologia, 432, 217-227.

Adão H.M., 1991. Procambarus clarkii (Girard, 1852) (Decapoda; Cambaridae) Espécie exótica em Portugal - Considerações sobre a ecobiologia e aspectos da sua biologia populacional na barragem do Monte Novo (Alentejo, Portugal), Provas de aptidão pedagógica e capacidade científica, Universidade de Évora, Portugal.

Anastácio P.M. and Marques J.C., 1997. Crayfish, Procambarus clarkii, effects on initial stages of rice growth in the lower Mondego River valley (Portugal). Freshwater Crayfish, 11, 608-617.

Aquiloni L., Ilhéu M. and Gherardi F., 2005. Habitat use and dispersal of the invasive crayfish Procambarus clarkii in ephemeral water bodies of Portugal. Mar. Freshw. Behav. Physiol., 38, 225-236.

Arrignon J.C.V., Huner J.V. and Laurent P.J., 1990. L'écrevisse Rouge des Marais, Maisonneuve et Larose, Paris, $87 \mathrm{p}$.

Correia A.M., 1995. Population dynamics of Procambarus clarkii (Crustacea: Decapoda) in Portugal. Freshwater Crayfish, 8, 276-290.

Correia A.M., 2002. Niche breadth and trophic diversity: feeding behaviour of the red swamp crayfish (Procambarus clarkii) towards environmental availability of aquatic macroinvertebrates in a rice field (Portugal). Acta Oecologica, 23, 421-429.

Correia A.M., 2003. Food choice by the introduced crayfish Procambarus clarkii. Annales Zoologici Fennici, 40, 517-528.

Correia A.M. and Anastácio P.M., 2008. Shifts in aquatic macroinvertebrate biodiversity associated with the presence and size of an alien crayfish. Ecol. Res., 23, 729-734.

Costanza R., D’Arge R., De Groot R., Farber S., Grasso M., Hannon B., Limburg K., Naeem S., O’Neill R.V., Paruelo J., Raskin R.G., Sutton P. and Van Den Belt M., 1997. The value of the world's ecosystem services and natural capital. Nature, 387, 253-260.

Cruz M.J. and Rebelo R., 2007. Colonization of freshwater habitats by an introduced crayfish, Procambarus clarkii, in Southwest Iberian Peninsula. Hydrobiologia, 575, 191-201.

Ferreira M.T. and Moreira I.S., 1999. River plants from Iberian basin and environmental factors influencing their distribution. Hydrobiologia, 415, 101-107.

Fidalgo M.L., 1990. Biology of the freshwater shrimp Atyaephyra desmarestii Millet (Decapoda: Natantia) in the river Douro, Portugal. II: Feeding rate and assimilation efficiency. Publ. Inst. Zool. "Dr. A. Nobre", 223, 1-19.

Fidalgo M.L. and Gerhardt A., 2002. Distribution of the freshwater shrimp, Atyaephyra desmarestii (Millet, 1831) in Portugal (Decapoda, Natantia). Crustaceana, 75, 1375-1385.

Flint R.W. and Goldman C.R., 1975. The effects of a benthic grazer on the productivity of littoral zone of Lake Tahoe. Limnol. Oceanogr., 20, 935-944.

García-Berthou E., 2001. Size and depth-dependent variation in habitat and diet of the common carp (Cyprinus carpio). Aquat. Sci., 63, 466-476.

García-Berthou E., 2002. Ontogenic diet shifts and interrupted piscivory in introduced Largemouth Bass (Micropterus salmoides). International Review of Hydrobiology, 87, 353-363. 
García-Berthou E. and Moreno-Amich R., 2000a. Food of introduced pumpkinseed sunfish: ontogenetic diet shift and seasonal variation. J. Fish Biol., 57, 29-40.

García-Berthou E. and Moreno-Amich R., 2000b. Rudd (Scardinius erythrophtalmus) introduced to the Iberian Peninsula: feeding ecology in Lake Banyoles. Hydrobiologia, 436, 159-164.

Garvey J.E., Stein R. and Thomas H., 1994. Assessing how fish predation and interspecific prey competition influence a crayfish assemblage. Ecology, 75, 532-547.

Geiger W., Alcorlo P., Baltanás A. and Montes C., 2005. Impact of an introduced crustacean on the trophic webs of Mediterranean wetlands. Biological Invasions, 7, 49-73.

Geraldes A. and Collares-Pereira M., 1995. Preliminary insight into age and growth of the iberian chub (Leuciscus pyrenaiscus) in the Sorraia system. Folia Zoologica, 44, 159-165.

Gerhardt A., Janssens De Bisthoven L. and Soares A.M., 2004. Macroinvertebrate response to acid mine drainage: community metrics and online behavioural toxicity bioassay. Environ. Pollut., 130, 263-274.

Gil-Sánchez J.M. and Alba-Tercedor J., 2002. Ecology of the native and introduced crayfishes Austropotamobius pallipes and Procambarus clarkii in southern Spain and implications for conservation of the native species. Biol. Conserv., 105, 75-80.

Guan R.Z. and Wiles P.R., 1997. Ecological impacts of introduced crayfish on benthic fishes in a British lowland river. Conserv. Biol., 11, 641-647.

Heck K.L. and Crowder L.B., 1991. Habitat structure and predator-prey interactions in vegetated aquatic system. In: Bell S.S., McCoy E.D. and Mushinsky K.R. (eds.), Habitat Structure: The Physical Arrangements of Objects in Space New York, Chapman and Hall.

Hobbs H., Jass J. and Huner J., 1989. A review of global crayfish introductions with particular emphasis on two North American species. Crustaceana, 56, 299-316.

Holdich D.M., 1999. The negative effects of established crayfish introductions. In: Gherardi F. and Holdich D.M. (eds.), Crayfish in Europe as Alien Species, How to Make the Best of a Bad Situation?, A.A. Balkema, Rotterdam, 31-47.

Ilhéu M., 2004. Padrões de uso de habitat da Ictiofauna em rios de tipo Mediterrâneo, Ph.D. Dissertation, Universidade de Évora, Portugal.

Ilhéu M. and Bernardo J.M., 1993. Aspects of trophic ecology of red swamp crayfish (Procambarus clarkii Girard) in Alentejo, South of Portugal, Actas VI Congreso Español de Limnología, Granada, 417-423.

Ilhéu M. and Bernardo J.M., 1995. Trophic ecology of red swamp crayfish Procambarus clarkii (Girard) preferences and digestibility of plant foods. Freshwater Crayfish, 10, 132-139.

Jordan F., Deleon C.J. and McCreary A.C., 1996. Predation, habitat complexity and distribution of the crayfish Procambarus alleni within a wetland habitat mosaic. Wetlands, 16, 452-457.

Levins R., 1968. Evolution in changing environments. In: Monographs in Population Biology, Vol. 2, Princeton University Press, Princeton, New Jersey.

Lodge D.M., Stein R.A., Brown K.M., Covich A.P., Brönmark C., Garvey J.E. and Klosiewski S.P., 1998. Predicting impact of freshwater exotic species on native biodiversity: challenges in spatial scaling. Aust. J. Ecol., 23, 53-67.

Lodge D.M., Taylor C.A., Holdich D.M. and Skurdal J., 2000. Nonindigenous crayfishes threaten North American freshwater biodiversity: lessons from Europe. Fisheries, 25, 7-20.

Magalhães M.F., Beja P., Canas C. and Collares-Pereira M.J., 2002. Functional heterogeneity of dry-season fish refugia across a Mediterranean catchment: the role of habitat and predation. Freshwater Biol., 47, 1919-1934.

Meurisse-Génin M., Reydams-Detollenaere A., Donatti O. and Micha J.C., 1985. Caractéristiques biologiques de la crevette d'eau douce Atyaephyra desmaresti Millet dans la Meuse. Annales de Limnologie, 21, 127-140.

Momot W.T., Gowing H. and Jones P.D., 1978. The dynamics of crayfish and their role in ecosystems. Am. Midl. Nat., 99, 10-35.

Nyström P., Svensson O., Vensson O., Lardner B., Brönmark C. and Granéli W., 2001. The influence of multiple predators on a littoral pond community. Ecology, 82, 1023-1039.

Oscoz J. and Durán C., 2005. Contribution to the knowledge of the freshwater shrimp, Atyaephyra desmaresti (Millet, 1831) (Decapoda, Natantia), in the Ebro basin (Spain). Zool. Baetica, 16, $155-159$. 
Ramos M.A. and Pereira T.M., 1981. Um novo Astacidae para a fauna portuguesa: Procambarus clarkii (Girard, 1852). Boletim Instituto Nacional Investigação e Pescas, 6, 37-47.

Renai B. and Gherardi F., 2004. Predatory efficiency of crayfish: comparison between indigenous and non-indigenous species. Biological Invasions, 6, 89-99.

Rodríguez C.F., Bécares E., Fernández-Aláez M. and Fernández-Aláez C., 2005. Loss of diversity and degradation of wetlands as a result of introducing exotic crayfish. Biological Invasions, 7, 75-85.

Schoener T.W., 1970. Non-synchronous spatial overlap of lizards in patchy habitats. Ecology, 51, 408-418.

Tittizer T., 1996. Main Donau Canal now a short cut for fauna. Danube Watch, 2, 7-8.

Vila-Escalé M., Rieradevall M. and Prat N., 2002. Estudio de la población de cangrejo rojo (Procambarus clarkii) sobre las comunidades vegetales sumergidas en dos torrentes del macizo de Sant Llorenç del Munt i L'Obac. In: Resúmenes del XI Congreso de la Asociación Española de Limnología y III Congreso Ibérico de Limnología, Cedex Publ., Madrid, 17-21.

Westman K., Savolainen R. and Julkunen M., 2002. Replacement of the native crayfish Astacus astacus by the introduced species Pacifastacus leniusculus in a small, enclosed Finnish lake: a 30-year study. Ecography, 25, 53-73.

Zar J.H., 1996. Biostatistical Analysis, Prentice Hall Inc., New Jersey. 